\title{
E-learning Based on Socio-Scientific Issues and Islamic Values: Post-Millennial Students in Madrasah
}

\author{
Vina Melinda ${ }^{1, *}$ \\ ${ }^{1}$ Science Education Postgraduate Program, Universitas Negeri Surabaya, Surabaya, Indonesia \\ ${ }^{*}$ Corresponding author. Email: vina.20012@mhs.unesa.ac.id
}

\begin{abstract}
Online learning in the COVID-19 pandemic era requires teachers and students to get used to the learning process using technology. This research aims to analyze the profile of E-learning used by Madrasah teachers in the COVID-19 pandemic era, as well as recommendations for learning approaches that can be integrated into Madrasah. The type of this research is literature research. The research method uses a literature study. Secondary data used the national and international journals that can be accounted for. The journal relates to the implementation of E-learning and the learning content in Madrasah. The data from journals that have been collected were analyzed descriptively qualitatively through a literature study. Several E-learning applications have been used well in various Indonesian Madrasah, but the learning content is still weak. The learning content provided by the teacher to students has not integrated scientific knowledge, students are not faced directly with problems that occur in the surrounding environment, even divine and moral education is less emphasized in E-learning. Researchers recommend creating E-learning based on Socio-Scientific Issues and Islamic Values (SSI-IV) as an alternative solution for the post-millennial students in Madrasah. The results of this research can be used as empirical evidence that E-learning needs to be developed, especially in the learning content section.
\end{abstract}

Keywords: COVID-19, E-learning, Islamic values, Madrasah (Islamic Based Schools), Post-millennial, Socio-scientific.

\section{INTRODUCTION}

Online learning is a solution for teachers and students during the covid-19 pandemic. All online learning cannot be separated from the use of technology [1-3]. Some of the problems that are often experienced when teachers deliver online learning materials, especially for the postmillennial generation (students born in 1995-2010), often tend to be unresponsive and lazy. Post-millennial students born in the digital era of communication and information are easily accessible. Conventional learning styles are not suitable for them, because technology has become a part of their lives [4]. The fact that postmillennials are often found is that they are more interested in various online games, social media, compared to the problems that exist around the environment where they live [5-6]. From the problems that arise, several factors that can influence students' interest in learning when learning online include appropriate digital learning, social support, emotional resilience, self-efficacy, active self-care [7].
Teachers are expected to package online learning into meaningful learning. Social issues that occur in Indonesia should be a motivation for post-millennial students in solving and resolving these problems [8]. In online learning, the three domains in the evaluation of learning in Indonesia must run in a balanced way, namely the cognitive, psychomotor, and affective domains. If these three realms work in harmony, then the post-millennial generation can solve problems that exist in society well and smoothly. In addition, the important role between teachers and parents must be balanced [9], parents monitor online learning at home, and teachers instill character education during learning [10]. All knowledge can be obtained easily through various sources, but the role of the teacher cannot replace technology in terms of character education [11].

E-learning that has been implemented turns out to still have some limitations, where e-learning has not been able to replace the role and advantages of conventional learning methods because the application provided is still simple [12-13]. Students cannot meet face-to-face, only 
do virtual videos. In this case, collaboration activities are also only carried out through virtual videos, so that faceto-face social interaction is reduced [32, 35-36]. From the problems that occur in online learning faced by postmillennial students, it is necessary to improve methods, appropriate learning strategies in online learning during the COVID-19 pandemic. Teachers must also always pay attention to the learning content given to their students.

The learning content presented to post-millennial students must be adapted to the situation around them. Therefore, the $21^{\text {st }}$ century skills of the post-millennial generation must always be taught, integrating socioscientific issues in e-learning, solving social issues that often occur later will be integrated with Islamic values so that the mentality of the post-millennial generation in a madrasah in particular protected and balanced between their cognitive and spiritual realms. In this case, the learning content delivered is not monotonous about formulas and theories, but rather towards implementing problems that occur in the surrounding environment, and no less important, namely the cultivation of character education, and religion in learning. A knowledgeable person is someone who does not forget his religious values $[13,16]$.

Therefore, the integration of technology and learning approaches in online learning is very important during the COVID-19 pandemic, especially in madrasah. In this case, it is necessary to further research the profile of the use of technology and learning approaches implemented in the online learning process during the COVID-19 pandemic.

\section{METHODS}

The type of this research is literature research. This research is limited to case studies regarding E-learning, so the research method uses a literature study. Secondary data used the national and international journals that can be accounted for. The journal relates to the implementation of E-learning and the learning content in madrasah. The data from journals that have been collected were analyzed descriptively qualitatively through a literature study. In general, the stages of data analysis in qualitative research are as shown in figure 1.

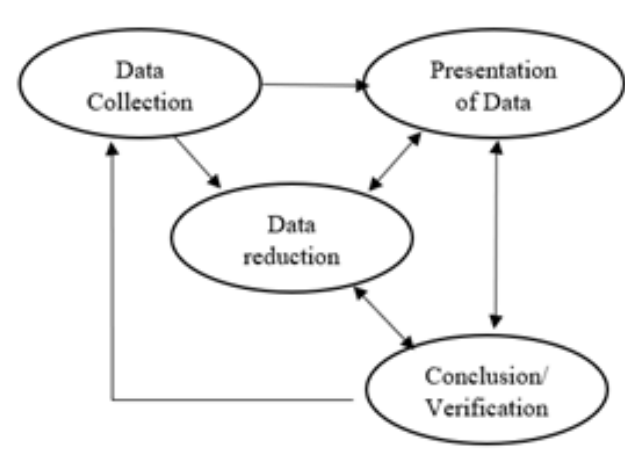

Figure 1 Qualitative data analysis chart.
Four stages in qualitative data analysis, namely:

1) Data collection, the data collection process is carried out by reviewing journals or experiments.

2) Data reduction, summarizing, and taking the main idea with the aim that the data obtained has a clear picture and makes it easier for researchers to take subsequent data.

3) Data Display (data presentation), data in qualitative research is presented in the form of narrative text in the form of charts, short descriptions, etc.

4) Conclusion and verification, conclusions and provide new findings that have not existed before.

\section{RESULTS AND DISCUSSION}

\subsection{Profile of E-learning for Post-Millennial Students during COVID-19 Pandemic}

Generation Z or post-millennial generation are people born between 1995-2010 [4]. The preferred learning method in this generation is in the form of text messages, learning to incorporate learning into the web with various learning management systems such as simulations, canvas and blackboards. This generation considers that mobile phones are portable computers [14].

The post-millennial generation is more required to be active in discussing, negotiating and solving problems. In constructivists, students are encouraged to actively participate in discussing, negotiating and solving problems. Learning activities are no longer just listening to the teacher explain the material, but also collaborating, thinking critically and communicating the results of problem-solving ideas. In this case, students are required to think high-level (HOTS) [4-5].

One of the online learning applications used in madrasah is Madrasah e-learning, this application has an important role in modern education, especially during the COVID-19 pandemic. E-learning for madrasah that has been applied in various madrasah has been going well and can facilitate online learning. The E-learning application for madrasah has been used by 19.235 madrasah, 137.538 teachers, 1,240,001 students and 229.449 online classes [15]. The implementation of Elearning in this madrasah includes lesson planning, learning process, learning administration, counselling, and assessment.

Before there COVID-19, several applications have been developed to support the learning process, such as Edmodo and the Moodle feature, these are used to help teachers share materials, increase the motivation of postmillennial students to learn about blended learning experiences [13-14]. According to [17], there are still some weaknesses using E-learning in madrasah which is influenced by the following factors: 


\subsubsection{Weak of natural resources}

In E-learning some teachers often do the following:

\subsubsection{Lack of motivation for students in learning}

In the era of the COVID-19 pandemic, environmental and psychological factors affect students' motivation, interest, and involvement in online learning. Teachers must design pedagogical so that students become motivated when online learning. Teachers must be able to optimize online learning and integrate technology in learning so that students are more motivated in dealing with the learning materials provided [18-20]. In addition, students' anxiety and stress levels in online learning can also reduce student motivation and this can hinder online learning [21] An important activity during online learning is collaborative technology supported and a balanced social environment, the presence of peers can increase students' motivation in learning [22].

\subsubsection{Lack of skills in the development of teaching materials}

According to some results of interviews with students, they argue that some teachers still teach conventionally, for example only giving textbooks that are less interesting and only monotonous reading, so students are less motivated in terms of learning. Teachers can take part in the training, the purpose of this training is to improve the professional knowledge, attitudes, and skills of teachers, so that online learning for students can run smoothly [23-24]. Learning materials are interactive, easy to understand by students, and can develop students' thinking patterns to become individuals who can solve problems in everyday life scientifically [37]. Students are trained to think at higher levels to solve problems in everyday life, rather than just learning about theories and formulas [25-26].

\subsubsection{Madrasah student's output has not been able to compete with other educational institutions.}

The features in e-learning are still not equipped with video conferences, so that teachers lack interaction in learning [13], even though teachers should also provide character education to students so that there is a balance between religion and scientific knowledge.

The E-learning application for madrasah is equipped with a counselling feature that helps students to consult related to the problems they face while studying [13]. But what often happens is that students lack confidence in expressing their arguments to their teachers. It's necessary to improve learning approaches and strategies so that students can get used to being brave and confident in dealing with problems in life based on relevant facts and scientific references, of course based on religion [27-
29]. Thus students will be familiar with the problems that exist in everyday life and will be able to compete with other students both at school and outside school.

\subsection{The Strength \& the Weaknesses of $E$ - learning in Madrasah during COVID-19 Pandemic}

\subsubsection{The strength of online learning}

Using E-learning for madrasah are flexible learning time, the material can be repeated, unlimited learning resources [30].

\subsubsection{1. flexible learning time of online learning}

Students can learn anytime and anywhere, not limited by space and time. Students can access learning easily without the need to travel to school because learning can be done from home [30]

\subsubsection{The material can be repeated}

The material given by the teacher can be recorded, only if at any time it is necessary to return the material can be opened and studied again. In addition, the Elearning feature has also been designed in a structured manner for madrasah in Indonesia. The use of E-learning can lead to self-pacing. At the time of asynchronous students can learn according to the ability to understand the speed of each material. It can therefore increase satisfaction [30].

\subsubsection{Unlimited learning resources}

Various references for learning are widely available for free on the internet. Students can easily access material on the internet. Students can study independently with the help of the internet to understand the material [30]. Students can also collaborate and discuss with their friends in solving a problem based on the references obtained [31].

\subsubsection{While some of the weaknesses of using E- learning for Madrasah are:}

\subsubsection{Students cannot meet face-to-face during learning.}

Direct interaction cannot be carried out, so students only meet with virtual videos. In this case, collaboration activities are also only carried out via virtual video, so that face-to-face social interaction is reduced [32, 35-36].

\subsubsection{Students are easy to cheat during exams}

During tests or learning evaluations, students have the potential to cheat on learning resources on the internet to find suitable answers to questions given by the teacher 
[33]. Usually what often happens is that students only copy and paste answers without understanding the questions given by the teacher, this tendency makes students' thinking patterns not develop properly, and students' morals, especially the honesty aspect, cannot be monitored properly.

\subsubsection{Students have the potential to find less reliable learning resources}

Some learning resources on the internet can be accessed by students. Usually, there are unreliable sources, this allows students to get lost in understanding the available material. This usually can lead to misconceptions among students [34].

\subsection{The Recommendation of E-learning for post-millennial Madrasah students in Indonesia}

From the problems faced by the post-millennial generation, researchers recommend an innovation in Elearning that integrates socio-scientific issues of learning with Islamic values. Socio-scientific issues (SSI) learning is learning that presents social issues related to science-related topics that are controversial so that it motivates students to debate, discuss in solve problems encountered [28]. SSI can improve students' conceptual understanding, student literacy, and problem-solving skills related to Higher-Order Thinking Skills (HOTS) [37-43]. In addition, ethical and moral reasoning with Islamic values is also involved in SSI-IV learning.

Figure 2 is the design of the solution, namely Elearning Based on Socio-scientific Issues and Islamic Values.

1. Core Element

2. Class environment

3. Peripheral influence

4. Islamic Values

5. Technology $[8,9]$

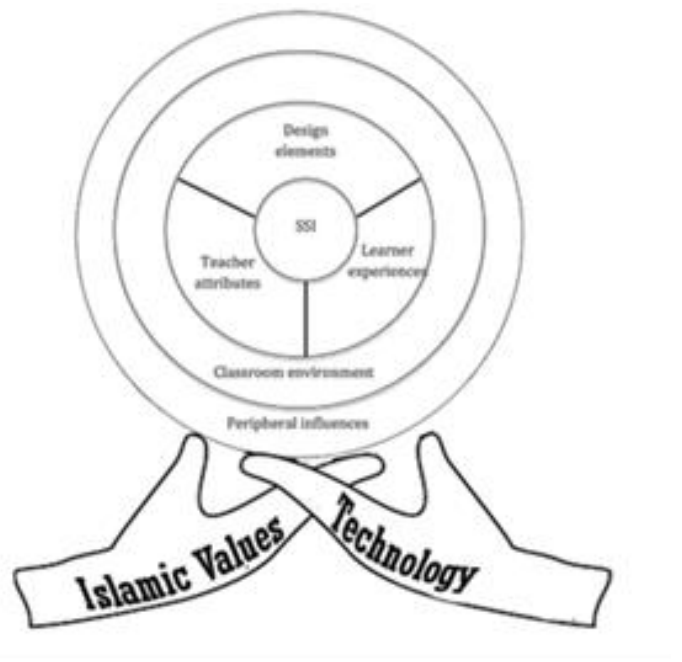

Figure 2 The framework of E-learning based on socio-scientific issues- Islamic values.

Figure 2 represents alternative solutions offered in Elearning in madrasah with the integration of Socioscientific issues and Islamic Values (SSI-IV) learning in it. In core layer 1 , the researcher recommends important aspects needed in SSI-IV learning. The socio-scientific issues framework was originally developed by [38].

\subsubsection{The Core element, it consists of three aspects, namely:}

\subsubsection{Design Element}

This aspect serves as the initial planning used by the teacher by conducting SSI-IV. The activities of the teacher include:

- Motivating students to be involved in learning by presenting interesting issues.

- Prepare students to experiment with higher-order thinking skills (e.g., reasoning, argumentation, evaluating, and making decisions)

- Provide scaffolding for students to solve the issues they face.

- Provide continuous learning experiences

\subsubsection{Learner experience}

Expected student activities in this case are:

- Engage in higher-order thinking skills, eg, reasoning, argumentation, decision making

- Facing and trying to solve the issues faced scientifically based on the theory

- Collect and/or analyze scientific data related to the issues at hand.

- Consider the social (e.g., economic, political, social and cultural) negotiation of the issues faced.

\subsubsection{Teacher attribute}

Teacher attributes that must be considered in providing material to students are:

- Understand the problems faced by: having scientific knowledge related to issues faced in society and referring to social considerations related to the problems faced.

- Teachers as learners, teachers must be open in terms of sharing their knowledge and willing to position yourself as a knowledge contributor.

- Deal with possible disagreements in the classroom.

\subsubsection{Classroom environmental}

The expected classroom conditions in learning based on Socio-Scientific Issues and Islamic values (SSI-IV) are:

- Collaborative and interactive with the environment. 
- High student participation.

- Tolerance between teachers and students.

- Students and teachers feel safe in the environment.

\subsubsection{Peripheral influences}

Several other aspects that influence the implementation of SSI learning are school, community, and national policies. Important features of this aspect include:

- Development of teaching materials that are following SSI-IV learning.

- Support for teachers in developing SSI-based learning includes cooperation with the community, teachers, parents.

- Flexible school curriculum policies so that teachers can implement SSI-IV

- Local wisdom of the school area related to the issues being faced.

- Strategy for overcoming concerns in online learning based on SSI-IV.

The circle that is built is protected by a representation of the shade of 2 hands which means that the elements in it must be protected or based on Islamic values and supported by technology as a facility in developing SSIIV learning.

\subsubsection{Islamic values}

Values are everything that becomes a reference in terms of acting and determining decisions in dealing with problems in life. According to Tajul Ariffin (1993), Islamic values refer to divine values, faith in Allah and centered on the Quran and Hadith. The Islamic values which are the foundation of the research of socioscientific issues refer to the verses of the Quran, Hadith and Islamic law that are following the socio-scientific issues faced. This Islamic value must be a guide for students in stepping into everyday life. So, not only cognitive students are trained in this e-learning, but also the aspects of divinity, development of religious-spiritual potential, self-control abilities and various skills that can later be implemented in the life of society, nation and state.

\subsubsection{Technology}

Technology is the most important facility in elearning, here the post-millennial generation is no stranger to the use of technology in their main learning activities during the COVID-19 period [44]. Technology becomes a facility in learning, in this case, technology can improve student learning outcomes in the learning process. Technology can make it easier for students to find learning resources, there are lots of learning resources that can be obtained using technology [45]. However, some of the weaknesses of this technology can affect students' laziness and mentality, if not used wisely. The big challenge for a teacher is that the integration of technology and materials must be balanced, the teacher should be able to provide interesting teaching for students so that post-millennial students feel motivated by the online learning provided by the teacher [46-47]. Therefore, the relation of human resources, technology, Islamic values, and science must be able to run in balance in the learning process, so that a post-millennial generation can be created that can be useful for the homeland, nation and religion [16, 48-50].

The results of this research can be used as empirical evidence that E-learning in madrasah needs to be developed, especially in the learning content section. This is intended so that learning is meaningful, not monotonous and post-millennial students can be more active in online learning activities. In this case, students hone the knowledge gained based on the problems that exist around students. Then students try to solve the social problem scientifically. Students not only listen to the teacher explain the material but also actively care about social problems in the community. In addition, not only the cognitive aspect of learning content is emphasized on students, but also students' moral attitudes and psychomotor skills are taught. Postmillennial students are taught to solve problems and problems around them while still based on appropriate Islamic values and supported by the technology used in the learning process. It's expected that learning can occur in a balanced manner, both from the cognitive, psychomotor, and attitude aspects

\section{CONCLUSION}

In this research, the implementation of E-learning during the COVID-19 pandemic has been carried out greatly by various madrasah in Indonesia. However, elearning applications used in online learning still need to be developed in more detail. Researchers recommend an alternative-solutions that can be implemented in the Elearning of post-millennial students, namely e-learning based on socio-scientific issues and Islamic values (SSIIV). Where in SSI-IV learning students are faced directly with controversial social issues in the environment they live in, which students then analyze scientifically and are based on Islamic values so that students can be trained in dealing with problems and remain based on religion. This research is limited to case studies regarding e-learning, further research is needed on the implementation of SSIIV-based learning in madrasah.

\section{AUTHOR CONTRIBUTIONS}

All author conceived and designed this study. All author contributed to the process of revising the manuscript, and at the end all authors have approved the final version of this manuscript. 


\section{REFERENCES}

[1] U. Hanifah Salsabila, L. Irna Sari, K. Haibati Lathif, A. Puji Lestari, A. Ayuning, Peran teknologi dalam pembelajaran di masa pandemi Covid-19, AlMutharahah, 17(2) (2020) 188-198.

[2] R. Raja, P.C. Nagasubramani, Impact of modern technology in education, Journal of Applied and Advanced Research, 3(1) (2018) 33-35.

[3] E. Cuff, The effect and importance of technology in the research process, Journal of Educational Technology Systems, 43(1) (2014) 75-97.

[4] P. Christine, I. D. Ienneke, Enhancing The PostMillennial Students Using Information Communication and Technology in learning English, Journal of Physics: Conference Series, 1477(4) (2020) 04202.

[5] K. Chitra, D. Jayanthi, G. Suganya, Post-Millennial generation's prudence on employability skills, Turkish Journal of Computer and Mathematics Education, 12(12) (2021) 104-112.

[6] S.F. Zis, N. Effendi, E.R Roem, Perubahan perilaku komunikasi generasi Milenial dan generasi $\mathrm{Z}$ di era digital, Satwika: Kajian Ilmu Budaya dan Perubahan Sosial, 5(2) (2021) 18-29.

[7] C. Koob, K. Schröpfer, M. Coenen, S. Kus, N. Schmidt, Factors influencing study engagement during the COVID-19 pandemic: A cross-sectional study among health and social professions students, PLoS ONE, 16(7) (2021) e0255191.

[8] A. R. Rahim, M. A. Samsudin, The effects of science learning based on the socio-scientific issues with islamic values on learners' attitudes towards the socio-scientific issues, Journal of Nusantara Studies, 2(2) (2017) 231-250.

[9] J. Hughes, O. M. Kwok, Influence of studentteacher and parent-teacher relationships on lower achieving readers' engagement and achievement in the primary grades, Journal of educational psychology, 99(1) (2007) 39.

[10] H.D. Puspita, The role of parents in educating children during online classes, Journal of Educational Research, 1(2) (2021) 69-75.

[11] L. Effriana, Problems of online learning during COVID-19 Pandemic in EFL classroom and the solution, JELITA, 2(1) (2021) 38-47.

[12] A.N. Hidayat, E-learning implementation in Islamic education innovation, HUNAFA: Jurnal Studia Islamika, 14(1) (2017) 17-36.
[13] H. Khotimah, H. S. Zainiyat, A. Hamid, A. Basit, Elearning application Madrasah online learning solution in the middle of pandemic COVID-19 in MA Negeri Insan Cendekia, Kendari, Technium Soc. Sci. J, 10(1) (2020) 107-114.

[14] L D. Rosen, L.M. Carrier, N.A. Cheever, Rewired understanding the iGeneration and the way they learn, Palgrave Macmillian Newyork, 2010.

[15] Kemenag RI. (n.d.), 2020 URL: https://Madrasah3.kemenag.go.id/elearning/web.

[16] E. Fahyuni, W. Wasis, A. Bandono, M. Arifin, Integrating Islamic Values and Science for millennial students learning on using seamless mobile media, Jurnal Pendidikan IPA Indonesia, 9(2) (2020) 231-240.

[17] A.S. Fahriana, M. Huda, Application of analysis of strengths, weaknesses, opportunities, and threats in islamic education institutions, Istawa: Jurnal Pendidikan Islam, 4(1) (2019) 50-64.

[18] T.K.F. Chiu, T. J. Lin, K. Lonka, Motivating online learning: the challenges of COVID-19 and Beyond, Asia Pacific Education Review, 30(3) (2021) 187 190.

[19] T.K.F. Chiu, Applying the self-determination theory (SDT) to explain student engagement in online learning during the COVID19 pandemic, Journal of Research on Technology in Education, (2021) 1-17.

[20] H.C.K. Hsu, C.V. Wang, C. Levesque-Bristol, Reexamining the impact of self-determination theory on learning outcomes in the online learning environment, Education and Information Technologies, 24(3) (2019) 2159-2174.

[21] R. Pekrun, S. Lichtenfeld, H. W. Marsh, K. Murayama, T. Goetz, Achievement emotions and academic performance: longitudinal models of reciprocal effects, Child development, 88(5) (2017) 1653-1670.

[22] K. Sormunen, From inclusive practices to personal strategies: Teachers and students designing digitally supported science learning, Nordic Studies in Science Education, 16(2) (2021) 234-234.

[23] R. Anggraini, Making in service teacher training effective through workshops, 3 rd International Conference on Education Teachers in the Digital Age Batusangkar, 2018.

[24] C. M. Z. C. Omar, The Need for In-Service Training for Teachers and It's Effectiveness In School, International Journal for Innovation Education and Research, 2(11) (2014) 1-9. 
[25] K.W. Lieung, D. P. Rahayu, U. Yampap, Interactive E-book to improve student's problem solving, Jurnal Ilmiah Sekolah Dasar, 5(1) (2021) 8-15.

[26] Asrowi. A. Hadaya, M. Hanif, The impact of using the interactive e-book on students' learning outcomes, International Journal of Instruction, 12(2) (2019) 709-722.

[27] M.S. Topcu, T.D. Sadler, O.Y. Tuzun, Preservice science teachers' informal reasoning about socioscientific issues: the influence of issues context, International Journal of Science Education, 32(18) (2010) 2475-2495.

[28] D.L. Zeidler, B.C. Herman, T.D. Sadler, New directions in socioscientific issues research, Disciplinary and Interdisciplinary Science Education Research, 1(1) (2019) 1-9.

[29] D.L. Zeidler, T.D. Sadler, S. Applebaum, B.E. Callahan, Advancing reflective judgment through socioscientific issues, Journal of Research in Science Teaching: The Official Journal of the National Association for Research in Science Teaching, 46(1) (2009) 74-101.

[30] V. Arkorful, N. Abaiddoo, The role of E-learning, the advantages and disadvantages of its adoption in Higher Education, Internasional. Journal Education Research, 2(12) (2014) 397-410.

[31] B. Gaille, Advantages and disadvantages of technology in education, 2018 URL: https://brandongaille.com/23-advantagesdisadvantages-technology-education

[32] Z. G. Shatri, Advantages and disadvantages of using information technology in learning process of students, Journal of Turkish Science Education, 17(3) (2020) 420-428.

[33] A. Borysiuk, Benefits and disadvantages of the use of information technologies in education, EdukacjaTechnika-Informatyka, 4(2) (2013) 110-114.

[34] N. Yusuf, K. A. Aziz, N. Al-Banawi. The impact of changing technology: the case of Elearning,.Contemporary Issues In Education Research, 6(2) (2013) 173-180.

[35] M. H. Assidiqi, W. Sumarni, Pemanfaatan Platform Digital dalam Pembelajaran Daring di masa Pandemi COVID-19, Prosiding Seminar Nasional Pascasarjana UNNES, 2020.

[36] N. Belova, I. Eilks, Promoting Societal-Oriented Communication and Decision-Making Skills by Learning about Advertising in Science Education, Center for Educational Policy Studies Journal, 4(1)
(2014) 31-49, URL:

https://files.eric.ed.gov/fulltext/EJ1129500.pdf

[37] T.D. Sadler, J.A. Foulk, P.J. Friedrichsen, Evolution of a model for socioscientific issue teaching and learning, International Journal of Education in Mathematics, Science and Technology, 5(2) (2017) 75-87.

[38] M.L. Presley, A.J. Sickel, N. Muslu, D.M. Johnson, S. B. Witzig, K. Izci, T. D. Sadler, A framework for socio-scientific issues-based education, Summer, 22(1) (2013) 26-32.

[39] Ş.Ö. Altınkaynak, The effect of interactive book reading activities on children's print and phonemic awareness skills, International Journal of Progressive Education, 15(1) (2019) 88-99.

[40] S. Siribunnam, P. Nuangchalerm, N. Jansawang, Socio-scientific decision making in the science classroom, Internasional Journal education research, 5(4) (2014) 1777-1782.

[41] D. Karisan, D. Zeidler, Contextualization of nature of science within the socioscientific issues framework: A review of research, International Journal of Education in Mathematics, Science and Technology, 5(2) (2017) 139-152.

[42] D. Zeidler, Sadler, S. Applebaum, B. Callahan, Advancing reflective judgment through socioscientific issues, 2009, URL: https://onlinelibrary.wiley.com/doi/epdf/10.1002/te a.20281

[43] E. Erman, D. A. P. Sari, Science in a black box: can teachers address science from socio-scientific issues?, Journal of Physics: Conference Series, 1417(1) (2019) 01209.

[44] L. Stošić, The importance of educational technology in teaching, International Journal of Cognitive Research in Science, Engineering and Education, 3(1) (2015) 111-114.

[45] S. Ghavifekr, W.A.W. Rosdy, Teaching and learning with technology: Effectiveness of ICT integration in schools, International Journal of Research in Education and Science, 1(2), (2015) 175-191.

[46] M. A. M. Kassem, Balancing technology with pedagogy in english language classroom: teachers' perspective, International Journal of English Language Teaching, 6(9) (2018) 1-19.

[47] B. Bauwens, J. Muylaert, E. Clarysse, M. Audenaert, A. Decramer, Teachers' acceptance and use of digital learning environments after hours: implications for work-life balance and the role of 
integration preference, Computers in Human Behavior, 112 (2020) 106479.

[48] Z. Zaitun, S. K. Wardani, Islamic values in the context of english learning and teaching, English Language in Focus, 1(1) (2018) 71-80.

[49] L. Listyono, K.I. Supardi, N. Hindarto, S. Ridlo, methods of integrating Islamic values in teaching Biology for shaping attitude and character, Journal of Physics: Conference Series, 983(1) (2018) 012178

[50] G. Rohmah, L. Hanifiyah, U. Fitriyah, A. Ningsih, Islamic values integration in English lesson at Madrasah Tsanawiyah: teachers' beliefs and practices, Jurnal Bahasa Lingua Scientia, 11(1) (2019) 93-106. 